\title{
Imagens da memória entre Roberto Bolaño e Walter Benjamin
}

\author{
Memory images between Roberto Bolaño and Walter Benjamin
}

\author{
Marcelo Santana Ferreira \\ Universidade Federal Fluminense
}

\section{RESUMO:}

O presente artigo é uma problematização da memória a partir do romance Amuleto de Roberto Bolaño, escritor chileno contemporâneo, e da concepção de história materialista em Walter Benjamin, em conexão com uma abordagem política da memória e da subjetividade em psicologia social. O propósito do artigo é defender uma concepção de memória que se relaciona com o tempo histórico decorrido, na articulação de um rastro que merece a atenção do presente. A personagem que ocupa o lugar de narradora no romance de Bolaño enfrenta dificuldades para estabelecer uma narrativa coerente e linear sobre a vivência traumática que experimentou na invasão militar de 1968 na Universidade Nacional Autônoma do México. No entanto, as dificuldades não são impeditivas para o empreendimento de um testemunho, que se subsidia na memória do passado e dos tempos vindouros, expressão do estatuto resistente e sobrevivente da recordação e da tarefa ética da literatura.

Palavras-chave: Roberto Bolaño; memória; Walter Benjamin.

\section{ABSTRACT:}

The present article is a problematization of memory based on the novel Amuleto by Roberto Bolaño, a contemporary Chilean writer and the conception of materialist history by Walter Benjamin, in connection with a political approach to memory and subjectivity in social psychology. The purpose of the article is to defend a conception of memory that relates to the historical time elapsed, in the articulation of a trail that deserves the attention of the present. The character who occupies the place of narrator in Bolaño's tale faces difficulties in establishing a coherent and linear narrative about the traumatic experience that she lived in the military invasion of 1968 at the UNAM. However, the difficulties are not impeding the undertaking of testimony, which is subsidized in the memory of the past and the times to come, expression of the resistant and surviving status of the memory and the ethical task of literature.

Key-words: Roberto Bolaño; memory; Walter Benjamin.

DOI: 10.12957/mnemosine.2020.57667

Dedico aos amigos Danichi Mizoguchi e Gabriel L. de Resende. 
"Não consigo esquecer nada. Dizem que é esse o meu problema" (BOLAÑO, 2008 :123)

\section{Apresentação}

No campo da psicologia social há heterogêneas concepções de subjetividade. No presente artigo, relacionamos subjetividade e memória, considerando que o exercício da recordação possa ser uma via de acesso privilegiada ao sentido histórico e político do tempo, como está explicitado na célebre pesquisa de Jean Pierre Vernant (2009) em psicologia histórica, debruçada sobre a lenta mutação da experiência da memória em parte das sociedades ocidentais. Vernant (2009) considera as transformações históricas e políticas que se deram no Ocidente em torno da definição da memória como algo inerente ao indivíduo, frisando a escrita de Santo Agostinho como provável desenho de um seminal processo de interiorização. Sem reduzirmos a compreensão da memória a uma faculdade psicológica e pessoal, nos dirigimos à perspectiva de defesa da recordação e da memória como oportunidade para um exercício de ampliação do estatuto político das imagens do passado. Consideraremos a memória como base para um empreendimento analítico e ético sobre o nosso tempo histórico, relacionando a escrita literária de Roberto Bolaño no romance Amuleto à historiografia reminiscente de Walter Benjamin.

Roberto Bolaño (2008) escreve Amuleto, romance que será discutido no presente artigo, convertendo materiais híbridos em parte de uma estrutura narrativa que se aproxima do testemunho. A narradora - Auxilio Lacouture, cidadã uruguaia presa num banheiro feminino da Faculdade de Letras da Universidade Nacional Autônoma do México em 1968, quando houve uma célebre invasão militar ao campus - entoa sua voz febril sobre o tempo histórico, apontando a estética arrojada de Bolaño, ferramenta que procuraremos manejar para defender a proximidade entre o exercício literário e as demandas histórico-políticas que nos são colocadas na atualidade em torno do tema da memória. Defenderemos um desdobramento do tema da memória em diálogo com a escrita literária.

O escritor chileno, morto precocemente em 2003, forja a personagem-narradora Auxilio Lacouture - que já havia aparecido em sua obra Os detetives Selvagens, em um capítulo breve (BOLAÑO, 2006) - empreendendo uma estética do exercício da memória pessoal e coletiva que tem grande importância para a compreensão ética e literária dos exercícios reminiscentes articulados em contextos institucionais de grande desqualificação das lutas pretéritas e atuais 
em torno da elaboração de uma concepção de história atenta aos riscos do apagamento compulsório do passado. No caso de Auxilio Lacouture, trata-se do exercício sobre a perda de uma geração de poetas - e de uma geração, simplesmente - vitimados pela contra-insurgência estatal e pela violência de Estado no México, dirigida, no final dos anos de 1960, a diferentes atores políticos, como o movimento estudantil. A personagem-narradora evoca jovens poetas assassinados, empurrados ao sacrifício exigido pelo Estado no estabelecimento de uma versão continuísta da história.

Considerada no romance em análise como a "mãe da poesia mexicana" e como "a testemunha do tempo seco" (BOLAÑO, 2008: 75), Lacouture mescla em sua narrativa aspectos muito importantes para a definição da relação entre memória e testemunho. Cidadã uruguaia, personagem limiar entre a comédia e a tragédia, Lacouture é uma sobrevivente que testemunhou parte da vida de poetas, professores(a)s e estudantes de arte e literatura no México em 1968 e anos anteriores. Parte significativa dos poetas não chegará, sequer, a ser lida. A personagem constitui o seu jorro narrativo a partir de referencialidades múltiplas, viabilizando o reconhecimento de vestígios políticos de diferentes momentos históricos. Circunscrevendo sua narrativa como um efeito do trabalho da memória sobre o tempo, a personagem pode nos ajudar a imergir no tempo histórico que ainda é o nosso, garantindo-lhe espessura e convidando-nos a um trabalho ético e interpretativo sobre a contemporaneidade. Não podemos deixar de considerar, também, que o romance pode nos dirigir ao estabelecimento de uma inteligibilidade política sobre os anos de 1960 e 1970, décadas em que suas personagens transitam e se deparam com diferentes sentidos de repressão e violência em países da América Latina, como Chile e México.

O romance de Roberto Bolaño em análise viabiliza uma problematização da memória e do trabalho do luto como exercícios estéticos e políticos, aproximando-se da concepção de história em Walter Benjamin, que garante ao conceito de experiência com o passado uma importância decisiva em sua epistemologia ética. Idelber Avelar (2003) já estabelecera importantes conexões entre o pensamento de Walter Benjamin e a emergência de uma literatura "pós-ditatorial” na América Latina, em que lugares enunciativos em escritas literárias assumem a perspectiva do luto como trabalho substitutivo e crítico em relação à impossibilidade de representação absoluta e narração do passado. No trabalho aqui proposto, defendemos que a personagem Auxilio Lacouture inventa procedimentos que garantem a aproximação entre o exercício narrativo na literatura e a defesa ético-política da elaboração da memória e do luto na 
filosofia benjaminiana, desdobramento também salientado em distintos comentários sobre a recepção da obra de Roberto Bolaño no Brasil (PEREIRA \& RIBEIRO, 2016). Na construção da personagem, Bolaño (2008) articula uma imagem das testemunhas improváveis, cujo olhar sobre o passado pode alcançar um dos índices do presente.

A personagem, absorta em sobreviver e assistindo à violência cometida aos seus contemporâneos, consegue esconder-se no banheiro feminino da "Faculdade de Filosofia e de Letras" por alguns dias. Será no banheiro que a personagem decidirá resistir, ou melhor ainda, recordar. $\mathrm{O}$ vertiginoso trabalho forjado sobre si e sobre as imagens difusas do tempo tornam Lacouture uma personagem de grande magnitude para nossa discussão, ao mesmo tempo que garante a presença da literatura de Bolaño como uma das linhas de composição heterogênea de nossa concepção do tempo histórico recente na América Latina. Lacouture chega ao México em 1965, data imprecisa, depois de ter ficado certo tempo em Buenos Aires. Ela viaja para encontrar alguns jovens poetas e, quando lhe surge a oportunidade, se oferece para trabalhar na casa de León Felipe e Pedro Garfias. Eventualmente, realiza algum trabalho para outras pessoas. Quando somos apresentados a Lacouture, imediatamente somos situados em relação a um problema considerado essencial por Bolaño, a relação entre a literatura e a vida.

Sem saber como ajudar no cotidiano dos poetas, a personagem procura mostrar sua serventia na retirada da poeira das lombadas dos livros. Um dos poetas lhe diz que “(...) a poeira sempre se entendeu com a literatura." (BOLAÑO, 2008: 11). A personagem estabelece um importante procedimento no início de sua narrativa, evocando as nuvens de poeira de seu pampa particular, além de ser o pampa de todos, uma poeira que temporaliza e institucionaliza o contexto de esquecimento que constitui parte da identidade latino-americana. Mas a personagem estabelece uma relação distinta com a poeira, insistindo no escrutínio das imagens do tempo, lembrando, deixando-se interferir na suposta continuidade do tempo, confundindose quanto à sequência dos anos, resistindo ao apagamento definitivo da geração que foi esmagada pela violência de Estado.

(...) e então tudo ficava coberto pela poeirada, os livros que eu havia lido e os livros que pensava ler, e aí já não havia nada que fazer, por mais que usasse a vassoura e o pano de pó a poeira nunca iria embora, porque essa poeira era parte consubstancial dos livros, e ali, à sua maneira, eles viviam ou remendavam algo parecido com a vida. (BOLAÑO, $2008: 11$ )

A personagem será definida como aquela que recorda, a mãe caminhante, a testemunha. O tempo do testemunho - tempo do texto - se elabora por intermédio da relação entre coisas que foram vividas, coisas que são lembradas, coisas que são esquecidas, coisas que são 
desejadas, antecipações em relação ao tempo. Nunca se está numa posição definitiva em termos de política temporal da narrativa. A discussão sobre a relação entre a literatura e a vida se torna parte consubstancial da compreensão do sentido ético do exercício literário, como defendido, por exemplo, por Diana Klinger (2014) ao sugerir uma “conversão" - um dos sentidos possíveis da bela leitura realizada pela autora sobre parte da literatura latino-americana contemporânea de escritas realizadas a partir de nossa própria memória a escritas com sentido filosófico e político, resistentes ao efeito puramente psicológico de narrar, uma vez que é a própria narrativa que resta como material heterogêneo que não sucumbe ao apagamento do tempo vivido e recordado. Na sugestão de Klinger (2014), torna-se possível aproximar a literatura de uma problematização de natureza ética do tempo histórico, do desejo e da esperança.

Perdendo-se a objetividade fria e neutra que se quer expandir sobre o passado, a narrativa de Lacouture no romance de Roberto Bolaño se espraia sobre os tempos, interrompendo a fatalidade da continuidade histórica. Muitas vezes, a personagem evoca um vaso de flores que havia na casa dos jovens poetas, para o qual um deles lançava seu olhar. Saberia o poeta o que se esconde dentro do seu vaso de flores? "Sabem os poetas o que se entoca na boca sem fundo dos seus vasos?' (BOLAÑO,2008 :14). Interrogando desse e de outros modos o exercício dos poetas, a narradora indica a possibilidade de relacionar o exercício poético com a responsabilidade sobre o tempo, uma espécie de trabalho sobre camadas de acontecimentos que talvez devessem ser esquecidos, mas que são evocados em um trabalho de elaboração do passado, procedimento em que escrita literária e memória convergem. Além disso, há uma importante convergência com a proposição de uma historiografia reminiscente no pensamento de Walter Benjamin, intérprete seminal da relação entre elaboração psíquica e política do passado no século passado. Na obra de Walter Benjamin, a discussão sobre memória possui uma singularidade, em que diferentes sentidos de lembrar são importantes. Para a discussão aqui sugerida, defendemos a transição de uma abordagem apenas pessoal da memória em direção a uma conceitualização política do lembrar. Recordação e reminiscência não são necessariamente sinônimos. A força das imagens que sobressaem de um fluxo contínuo de atenção e conexão com o tempo se aproxima da defesa de uma historiografia que se apodera daquilo que é lembrado com a preocupação de tornar o passado transmissível. A complexidade da discussão linguística e política da memória em Benjamin viabiliza que as definições de recordação, reminiscência e lembrança nem sempre coincidam. 


\section{Uma "experiência com o passado" em Roberto Bolaño e no pensamento de Walter Benjamin}

Lacouture faz um inventário de sua chegada à Cidade do México, confundindo-se quanto às datas, dialogando consigo mesma, sendo interpelada por vozes que tornam ainda mais espesso o contexto histórico em disputa. A memória da personagem é um antídoto contra o esquecimento compulsório, bem como contra a pretensão de que nada poderia ser esquecido. Situando-se no limiar do esquecimento que se quer reiterar e daquele que se desejava purgar, a atividade reminiscente de Lacouture encontra as noites da vida boêmia dos poetas da Cidade do México. Lembra da vida universitária às vésperas da invasão militar e parece, muitas vezes, se confundir. Ao evocar um professor universitário da Universidade Nacional Autônoma do México em sua conversa com alunos sobre aspectos da poesia de Ovídio, Lacouture insiste em trabalhar sobre as próprias lacunas da lembrança: “(..) de que falamos, Virgem Santa, de que falamos? Não me lembro com exatidão" (BOLAÑO, 2008 :20). O escritor viabiliza que, por intermédio da narradora, se performatize uma relação com o tempo passado. $\mathrm{O}$ fato de não haver uma exatidão sobre aquilo que se viveu não inviabiliza que se persista no trabalho de elaboração de uma imagem do passado. É nessas ruínas do passado, nos estilhaços de silêncios e balbucios no interior das conversas universitárias e boêmias que Lacouture recupera uma imagem geracional e uma imagem de si mesma, coadunando o trabalho reminiscente com uma possibilidade de subjetivação, mesmo que a condição do sujeito seja sempre precária em relação ao que procura inventariar. Ao considerarmos o conceito de sujeito a partir da crítica de Michel Foucault aos universais antropológicos e da abordagem de Giorgio Agamben (2016) a respeito da relação entre subjetividade e ética, pensamos que haja uma indissociabilidade entre processos de subjetivação e de dessubjetivação, como os que estão em curso nos projetos de governamentalização biopolítica em sociedades contemporâneas.

Em texto originalmente publicado em 1982, Michel Foucault (2014/1982) caracterizou o tema do sujeito em suas investigações, sem recair em nenhum substancialismo ou perspectiva trans-histórica.

Procurei(...) produzir uma história dos diferentes modos de subjetivação do ser humano em nossa cultura; tratei, nessa ótica, dos três modos de objetifivação que transformam os seres humanos em sujeitos.

Há, inicialmente, os diferentes modos de investigação que procuram aceder ao estatuto de ciência; penso, por exemplo, na objetivação do sujeito, falando de gramática geral, de filosofia e de linguística. Ou, então, sempre nesse primeiro modo, na objetivação do sujeito produtivo, do sujeito que trabalha, em economia e na análise das riquezas. Ou, ainda, (...) na objetivação somente do fato de estar em vida, na história natural ou na biologia. 
Na segunda parte do meu trabalho, eu estudei a objetivação do sujeito no que chamei de "práticas divisoras". O sujeito ou é dividido no interior dele mesmo, ou dividido dos outros. Esse processo faz dele um objeto. A separação entre o louco e o homem são de espírito, o doente e o indivíduo em boa saúde, o criminoso e o "rapaz gentil" ilustra essa tendência.

Enfim, procurei estudar(...) a maneira como um ser humano se transforma em sujeito; orientei minhas pesquisas para a sexualidade, por exemplo, a maneira como o homem aprendeu a se reconhecer como sujeito de uma "sexualidade. (FOUCAULT, 2014/1982:118119)

Na continuidade de seu panorama sobre a própria obra, Foucault (2014/1982) procura mostrar como sua discussão sobre o tema do sujeito não esteve separada da sua concepção de poder. Destaca-se, no texto formulado como uma espécie de visada sobre sua própria obra, que Foucault (2014/1982) busca indicar a perspectiva genealógica sobre a subjetividade, sinalizando que assujeitamento e subjetivação viabilizam o reconhecimento de uma processualidade de sentido político e histórico. Lutas em torno da subjetividade, por exemplo, foram estabelecidas no século XX e ainda o são nas primeiras décadas do século atual a partir da possibilidade de não estarmos sempre fadados a nossas próprias identidades. Justamente nesta direção, Giorgio Agamben (2016) propôs a noção de biopolítica menor, ao sugerir que os esquemas macropolíticos, estatais e históricos em torno da condução da vida social se dirigem ao fato de que somos seres viventes e que nossa própria vida biológica entra nos mecanismos de gestão das sociedades. Lembra o pensador italiano que a cisão inventada historicamente entre zoé e bios - simultaneamente, significando, em grego, o fato de viver como algo comum a todos os seres vivos e a maneira de viver de um ser singular ou grupo (REVEL, 2011:152) não se sustenta no desenvolvimento de projetos políticos de condução da existência em sociedade, dirigindo-se à consideração do caráter de "resto" de experiências políticas e subjetivas que resistem à dicotomia, ao estabelecerem uma abertura inconclusa em termos de processos de elaboração de si, de relação a si mesmo. Assim, Agamben (2016) buscou considerar a noção de testemunha ao lidar com os rastros narrativos a respeito dos campos de concentração nazistas. Não existiria testemunha integral, problema que se desdobra na composição precária e resistente das enunciações sobreviventes e ativas politicamente.

A subjetividade é um território de disputas e de reflexão, abrindo-se à possibilidade de uma interpretação de materiais estéticos, como um romance literário que dialoga fortemente com seu próprio tempo histórico, como se trata em Amuleto. No romance de Roberto Bolaño em análise, o caráter fragmentário e não-finalizado da narrativa de Auxilio Lacouture se conecta com o sentido sobrevivente dos testemunhos históricos, mesmo com o aspecto de "resto" das 
lembranças que se tornam transmissíveis. O que resta da cultura dos anos de 1960 e 1970 no México, no Chile e em outros países latinoamericanos nos endereça ao que se constitui como paradigma dos tempos atuais, em curso, principalmente, nas políticas de memória assentadas no esquecimento do passado. De acordo com Oswaldo Giacoia Jr.(2015), a partir do pensamento de Giorgio Agamben e Walter Benjamin, pode-se pensar o sentido efetivo, ou seja, histórico, dos processos de subjetivação, relacionando subjetividade ao "resto" da relação entre subjetivação e dessubjetivação, como podemos defender em relação à personagem Auxilio Lacouture, que experimenta esquecimentos e riscos de anulação de si mesma no empreendimento da enunciação do passado e do que ainda não foi desdobrado ou reconhecido. De acordo com Giacoia Jr. (2015),

O sujeito não é fundamento, nem termo final de uma teleologia, mas um resto. Sob os termos que designam os processos históricos ( humano e inumano, homem e não-homem) não existe um fundamento, nem mesmo nesses próprios termos; há entre eles, no meio deles, uma distância e um afastamento irredutível, no qual todo termo pode pôr-se na condição de resto; pode, portanto, testemunhar. (p.15)

Os procedimentos em curso no romance de Bolaño atravessam e são atravessados pelo contexto histórico em que ainda nos encontramos, sustentando uma estética em que a literatura é interpelada pelos gritos e sonhos inauditos de uma geração. A composição do lugar enunciativo da narradora viabiliza o reconhecimento do estatuto relacional das ontologias em curso no livro, como aquelas das personagens e das vozes instituídas no tempo histórico estendido. Trancada no banheiro, o que a personagem-narradora encontra, quando se volta ao exercício da lembrança sobre o que antecedeu ao fatídico ano de 1968 ?

(...) me davam para ler seus poemas, seus versos, suas aflitas traduções, e eu pegava aqueles papéis, lia em silêncio, de costas para a mesa onde todos brindavam e procuravam angustiosamente ser engenhosos, ou irônicos, ou cínicos, pobres anjos meus, e mergulhava nessas palavras (gostaria de dizer fluxo verbal, mas faltaria com a verdade, ali não havia fluxo verbal, mas balbucios) até a medula, ficava por um instante a sós com essas palavras entorpecidas pelo brilho e a tristeza da juventude, ficava um instante a sós com esses pedaços esfacelados de espelho e me olhava, melhor dizendo, me procurava no reflexo dessa quinquilharia, e me encontrava!, lá estava eu, Auxilio Lacouture, os olhos azuis, os cabelos louros branqueando cortados à Príncipe Valente, a cara comprida e magra, as rugas na testa, e meи eи me estremecia, me submergia num mar de dúvidas, me fazia desconfiar do futuro, dos dias que se aproximavam com uma velocidade de cruzeiro, embora por outro lado me confirmasse que eu vivia com meu tempo, com o tempo que eu havia escolhido e com o tempo que me rodeava, agitado, mutável, pletórico, feliz.

E assim cheguei a 1968. Ou 1968 chegou a mim. (BOLAÑO, 2008:22)

A composição da personagem dá a ver um inquietante conjunto de questões formais com as quais o escritor se confrontou na articulação da sua obra, como a profusão de referências 
que estão em jogo em seus textos literários. Além disto, permite que a singularidade da obra se torne indissolúvel diante de possíveis classificações. Aqui, por exemplo, se tenta defender a proximidade do exercício literário com as narrativas de testemunho, sem, com isso, incorrer na definição estrita do romance como literatura de testemunho. Márcio Seligmann-Silva (2005) já apontara como houve uma tendência em considerar algumas obras literárias latinoamericanas como documentos históricos assentados na facticidade de referências subalternizadas, distanciadas da plurivocidade da memória e do caráter transversal de vetores de constituição da subjetividade que se forja na narração. No romance de Bolaño (2008) em análise, se trata, no nosso entender, de uma mixagem entre o trabalho literário e a articulação de uma perspectiva crítica sobre o tempo histórico, viabilizando uma ampliação do próprio sentido de histórico. Compreender o fruto nutritivo do que é interpretado como fonte histórica numa obra literária pode viabilizar a própria transcendência temporal da obra, sem que percamos de vista as condições históricas em que recebemos e lemos os próprios textos. Desta forma, podemos nos aproximar daquilo que Walter Benjamin (2008) já advertira em uma das suas Teses sobre o conceito de história:

O materialista histórico só se aproxima de um objeto histórico quando o confronta enquanto mônada. Nessa estrutura, ele reconhece o sinal de uma imobilização messiânica dos acontecimentos, ou, dito de outro modo, de uma oportunidade revolucionária de lutar por um passado oprimido. Ele aproveita essa oportunidade para extrair uma época determinada do curso homogêneo da história; do mesmo modo, ele extrai da época uma vida determinada e, da obra composta durante essa vida, uma obra determinada. Seu método resulta em que na obra o conjunto da obra, no conjunto da obra a época e na época a totalidade do processo histórico são preservados e transcendidos. O fruto nutritivo do que é compreendido historicamente contém em seu interior o tempo, como sementes preciosas, mas insípidas. (BENJAMIN, 2008: 231)

Walter Benjamin (2008) descreve, no texto de sua autoria que é muitas vezes aproximado de um testemunho filosófico, uma metodologia não teleológica a respeito da recepção de uma obra, da aproximação filosófica a um objeto histórico. Há um vetor de complexificação da experiência da leitura e da crítica, já que as fontes históricas não são simplesmente comunicadas, mas aproximadas do trabalho estético. A literatura permite uma conversão da linearidade em espessura temporal, uma vez que viabiliza que nos aproximemos da época histórica sem retirar o invólucro que permitiu que a obra chegasse até nós. Tornar as sementes históricas mais saborosas no processo de leitura pode significar permitir que seu poder germinativo atinja a nossa crítica cultural, avançando no trabalho interpretativo e político de elaboração do passado. Já que o passado não é uma facticidade absoluta, a sua elaboração depende de um exercício de memória, que é ressaltado na articulação da personagem Auxilio 
Lacouture por Roberto Bolaño. Situando a sua personagem-narradora em Amuleto, Bolaño (2008) ficcionaliza fragmentos da atividade reminiscente que se apodera, provisoriamente, do passado sem recair no realismo histórico dos quadros que se seguem no fio narrativo. O texto de Bolaño pode ser interpretado como mônada que reflete e refrata contextos históricos que revelam uma imagem de nós mesmos. Polifônico, o romance de Bolaño (2008) nos atinge. Interpretar/ler o romance é, de certa forma, insistir na produção de novas conexões temporais com o que está escrito, revelando, também, "onde" nos encontramos.

Para Walter Benjamin, o conceito de experiência e, especificamente, a "experiência com o passado" assume grande importância, uma vez que, ao caracterizar a modernidade como limiar temporal e político em que se tratava exatamente do declínio da narratibilidade e da transmissibilidade assentada na sabedoria e na relação entre narradores e ouvintes - nas sociedades do modo de produção artesanal - em direção à centralidade da informação e da imprensa informativa, a ciência histórica sobre o passado se vê diante de um problema de natureza ética e cognitiva. O passado seria uma matéria inerte, impermeável aos esforços de legibilidade adotados no decorrer do tempo histórico? Walter Benjamin (2008) faz críticas ao historicismo continuísta, que trabalha com a sucessão natural entre presente, passado e futuro, encaminhando-se a uma teleologia, sugerindo uma proximidade entre o historiador e o narrador, chegando a considerar que o historiador materialista - aquele que busca caracterizar e defender, a partir de sua leitura do pensamento marxista - poderia ser pensado como um cronista da história, aquele que não diferencia os pequenos dos grandes acontecimentos.

Lacouture se encontra entre o sono e a vigília, evocando encontros entre os tempos históricos, entre as vozes do passado, do presente e do futuro, oportunamente podendo ser relacionada com a pretensão metodológica formulada por Walter Benjamin (2008) em relação ao sentido do tempo em sua historiografia materialista, supondo que haveria um encontro secreto marcado entre as gerações precedentes e a nossa (p.223). Benjamin (2008) deixara explícito em suas Teses sobre o conceito de história o quanto se tratava, para a ciência histórica que defendia, de estabelecer uma experiência com o passado e, não mais, a pretensão de descrever o passado como ele, de fato, foi. $\mathrm{Na}$ experiência com o passado, o encontro entre gerações se torna viável:

O passado traz consigo um índice misterioso, que o impele à redenção. Pois não somos tocados por um sopro do ar que foi respirado antes? Não existem, nas vozes que escutamos, ecos de vozes que emudeceram? Não têm as mulheres que cortejamos irmãs que elas não chegaram a conhecer? Se assim é, existe um encontro secreto, marcado entre as gerações precedentes e a nossa. Alguém na terra está à nossa espera. (BENJAMIN,2008: 223) 
A perspectiva ético-metodológica de Walter Benjamin se define por uma experiência com o passado, evocada também em seu célebre texto sobre a obra de Nikolai Leskov, em que se tematiza o lugar enunciativo de narradores e narradoras da tradição oral como via de passagem daquilo que se ouviu para uma comunidade de ouvintes atentos e descentrados de si mesmos. Leskov foi um escritor russo do século XIX que mantinha em seus textos a presença crítica e não familiar dos contadores de história. Ao considerar que o encontro secreto das gerações atuais se fará com as gerações precedentes, Benjamin sugere a importância do trabalho reminiscente na base da ciência histórica que defende, o que revela, em certa medida, "como" lembramos do passado, ou ainda, como ainda podemos citar o passado em seu estatuto fulgurante, provisório.

Apesar de, em muitos momentos, Lacouture se sentir deslocada em relação a qualquer experiência a partir daquilo que vivencia e daqueles de que lembra, podemos reconhecer uma importante proximidade entre o jorro narrativo da cidadã uruguaia que recorda e a inquietação ético-política do pensador judeu alemão na formulação de uma historiografia reminiscente.

Exatamente em torno da definição da historiografia benjaminiana como efeito de uma experiência com o passado, podemos recuperar o sentido teórico-político da experiência como limiar e travessia, quando, por exemplo, Jeanne Marie Gagnebin (1994) faz uma arqueologia da noção de desorientação no diagnóstico do homem moderno no pensamento de Benjamin. Estabelecendo uma convergência entre a figura do narrador e a figura do moribundo, Gagnebin (1994) lembra parte significativa da discussão empreendida por Benjamin ao considerar a obra de Nikolai Leskov:

Lembremos aqui que a palavra Erfahrung vem do radical fahr-usado ainda no antigo alemão no seu sentido literal de percorrer, de atravessar uma região durante uma viagem. Na fonte da verdadeira transmissão da experiência, na fonte da narração tradicional há, (...) esta autoridade que não é devida a uma sabedoria particular, mas que circunscreve o mais pobre homem na hora de sua morte, escreve Benjamin no parágrafo X de 'O Narrador'. (p.66)

Circunscrevendo a interpretação benjaminiana historicamente e relacionando, também, a reflexão do pensador sobre a figura do narrador aos desdobramentos críticos formulados sobre a obra de Benjamin, Gagnebin (1994) sugere a centralidade da noção de travessia na conceitualização da experiência, categoria que terá grande importância para a formulação dos textos inter-relacionados na escrita derradeira de Walter Benjamin, as Teses sobre o conceito de história. Uma experiência com o passado, nos anos de 1940, se configura como legado 
crítico, como base de elaboração de um ethos, uma vez que é, justamente, o passado que deve ser apagado ou suprimido como forma de neutralização das vozes dissonantes e das vidas resistentes às violências históricas cometidas em relação a diferentes minorias. Benjamin posterga ao futuro uma legibilidade sobre o que enfrenta - pessoal e coletivamente - como projeto de destituição política e destruição física e simbólica. A autoridade do narrador se sustenta como uma base fundamental para a articulação do historiador materialista. A autoria da narrativa remete à travessia entre as vidas de quem conta e quem ouve uma história. Em tensão dialética com a noção de vivência - Erlebnis em alemão - o conceito de experiência se modifica em contexto histórico amplo, como parte do século XIX, no qual os interiores das casas burguesas se enchiam de referências pessoais - próprias - dos donos das moradias em contexto de instrumentalização das massas e administração da sensibilidade coletiva. Os rastros nos ambientes públicos devem ser suprimidos, como forma de sobrevivência às perseguições políticas e ao projeto de condução da vida pessoal e coletiva que se espraiou pelo mundo ocidental quando passa-se, também, a viver sob a exiguidade da novidade (GAGNEBIN, 1994: $71)$.

O declínio da experiência não impede que Benjamin defenda um conjunto de elementos essenciais para o estabelecimento de uma epistemologia ética no campo da historiografia materialista. O narrador, autor não absoluto de uma história, testemunha dos tempos passados, emerge nos momentos de grande perigo individual e coletivo, exatamente as oportunidades de reconhecimento de uma imagem do passado. Fazer explodir o continuum da história considerada como norma, apropriar-se do passado como expressão de uma forma de elaboração política são exercícios concernentes à tarefa do historiador materialista. Contra a imagem eterna - fixa - do passado, um trabalho de elaboração política e epistemológica do tempo histórico.

A historiografia reminiscente de Walter Benjamin dialoga com a experimentação literária em curso em Roberto Bolaño, no nosso entender, pois a temporalidade espessa da história é imaginada esteticamente, por intermédio da assunção de um lugar marcado pelo perigo e pela precariedade, mas, fundamentalmente, pela atenção à oportunidade que surge, no tempo, para um desdobramento do passado. Buscando caracterizar a história materialista como imagética, Walter Benjamin estabelece o sentido ético do exercício de investigação histórica, movida pelas urgências do presente, persistindo, brevemente, na paradoxal possibilidade de citar o passado ocluído. Quando os inimigos retomam seu cortejo triunfal, quando movimentos de insurreição são mais uma vez ameaçados, quando as dissidências são patologizadas e 
perseguidas novamente, uma imagem do passado atravessa o presente, tornando-se viável, eticamente, ater-se ao agora, a partir do qual se busca forjar uma inteligibilidade sobre o tempo histórico. Nas idas e vindas da escrita de Bolaño (2008), somos convocados à composição do próprio texto que corta as continuidades autoevidentes. Assim também se dá na proposição do "agora de cognoscibilidade" em Walter Benjamin (2018)

$O$ índice histórico das imagens diz, pois, não apenas que elas pertencem a uma determinada época, mas, sobretudo, que elas só se tornam legiveis numa determinada época. E atingir essa "legibilidade" constitui um determinado ponto crítico específico do movimento em seu interior. Todo presente é determinado por aquelas imagens que lhe são sincrônicas: cada agora é o agora de uma determinada cognoscibilidade. (p.768)

A sincronia entre passado e presente se conecta com o empreendimento do "agora" de cognoscibilidade quando alguma possibilidade de conhecimento a respeito de si e do mundo se apresenta, independente das intenções daquele que lembra. Indicando que não se parte de uma escolha espontânea que estabeleceria um seccionamento do tempo, a historiografia reminiscente se exprime como atitude em relação ao que é lembrado, no momento de perigo pessoal e coletivo. Uma possibilidade de "conhecer" o presente é sentir-se visado por um índice histórico do passado e do presente. A experimentação literária em Amuleto se nutre da elaboração narrativa do entrecruzamento dos tempos, de sua simultaneidade, de seu extravasamento intensivo. A testemunha em Amuleto viabiliza que as enunciações se confundam e se espraiem, forjando imagens sobre o que diz respeito a si mesma e ao mundo, convocando, por intermédio da leitura, que também possamos elaborar uma legibilidade do presente e daquilo que foi suspenso e interrompido. Neste sentido, defendemos um limiar da experimentação literária com a ética da historiografia reminiscente.

\section{Elaboração do passado e o trabalho do luto}

Para viabilizar a continuidade de nossa leitura, vamos buscar aproximar a lembrança do passado do processo de elaboração e de luto, depois de termos transitado pelas considerações de Walter Benjamin sobre a articulação de uma historiografia reminiscente. Que estatuto teria o "agora" da perspectiva adotada por Auxilio Lacouture em relação ao passado? Que conexões podemos produzir entre o "agora" do testemunho de Lacouture e o estabelecimento de uma inteligibilidade sobre o passado? Inicialmente, a confirmação de que se vivera um episódio de grande sentido histórico e político, a partir da lembrança:

Ai, lembrar disso me faz rir. Que vontade de chorar! Estou chorando? Vi tudo e, ao mesmo tempo, não vi nada. Entendem o que quero dizer? Sou a mãe de todos os poetas e não permiti 
(ou o destino não permitiu) que o pesadelo me desmontasse. As lágrimas agora escorrem por minhas faces estragadas. Eu estava na faculdade naquele 18 de setembro em que o exército violou a autonomia e entrou no campus para prender ou matar todo o mundo. Não. Na Universidade não houve muitos mortos. (BOLAÑO, 2008 :23)

A personagem narra muitas vezes o que lhe aconteceu, afastada provisoriamente e decisivamente das pessoas com quem dividia a rotina na Universidade Nacional Autônoma do México em setembro de 1968. A personagem se vê sozinha no banheiro, sai e se depara com o silêncio do corredor, indo à janela e vendo professores, secretárias e alunos sendo enfiados em furgões, pessoas caindo pelo chão, recolhendo, de forma atabalhoada, papéis datilografados e outras pessoas que cobriam os seus narizes com um lenço branco que ia sendo tingido pelo sangue que escorria. Sozinha no banheiro feminino, a personagem se dá conta, precariamente, do que acontecia. Ainda remetida à sua própria latrina, a personagem se sobressalta com a entrada de um soldado que assegurava, depois de um tempo, que estava tudo certo. Os militares poderiam sair. Lacouture, então, se confronta a uma multiplicação vertiginosa do sentido do tempo, “(...) como se o tempo se fraturasse e corresse em várias direções a uma só vez, um tempo puro, nem verbal nem composto de gestos e ações(...)" (BOLAÑO, 2008 :27).

Gradativamente, a personagem começa a imergir numa experiência "louca" em que a sequência do tempo rui, o desejo de mergulhar no livro que trouxe à mão a esquenta, lê mais três poemas de Pedro Garfias e diz para si mesma: "Auxilio Lacouture, cidadã do Uruguai, latino-americana, poeta e viajante, resista." (BOLAÑO, 2008 :29). A narrativa se dirige a um enfrentamento subjetivo e político da situação extravagante em que se encontra. Não se pode sair do banheiro, mas até quando? O que acontecia fora do estrito espaço em que a narradora conseguiu se livrar da violência da invasão militar? Gradativamente, como leitores, seremos lançados ao cerne da narrativa difusa, paradoxal, em que o passado se torna o coração do presente enunciativo, do agora do texto, em que também o futuro se densifica, em que as datas se chocam, em que uma atividade literária inaugura, também, a possibilidade de ativar uma memória que concerne aos latinoamericanos, não apenas à personagem. Memória do passado, memória do futuro que atinge diferentes leitores que se encontram em distintos países da América Latina, como nós, agora, no Brasil contemporâneo, assombrados com a reiteração de um passado autoritário que ainda não passou: “(...) comecei a pensar no meu passado como se pensasse no meu presente, no meu futuro, no meu passado, tudo revolto e adormecido num só ovo morno, um enorme ovo de não sei que pássaro interior (um arqueópterix?) abrigado num ninho de escombros fumegantes.” (BOLAÑO,2008 :29). 
Não podemos perder de vista as distinções necessárias entre real, histórico e ficção, como apontadas por Márcio Seligman-Silva (2005) quando relaciona psicanálise, estudos culturais e diferentes momentos históricos da elaboração de uma literatura de testimonio $^{1}$ na América Latina, a partir dos marcadores históricos das ditaduras civis-militares e da profusão de esforços estéticos e teóricos para a articulação de lugares enunciativos a partir da consideração da subalternidade forjada socialmente. Considerando o exercício literário na fronteira com o trabalho de elaboração psíquica sobre o trauma, Seligmann-Silva (2005) procura defender o sentido de real como aquilo que resiste à representação, aproximando a enunciação do passado de uma espécie de tradução como tarefa e desistência, no caso das tradições de estudo estabelecidas na Europa e nos Estados Unidos do século XX, pós Segunda Guerra Mundial. No caso da América Latina, Seligmann-Silva (2005) indica a força dos argumentos que se voltam à valorização da experiência coletiva de subalternidade, o que seria índice de um trabalho crítico sobre a produção da opressão e a produção de lugares privilegiados de articulação de uma imagem da história. A estética de Bolaño (2008) se elabora numa espécie de atividade de dobra da literatura sobre si mesma, ao valorizar citações que as personagens se fazem, ao buscarem vestígios de textos literários em sua tensão histórico-política com imagens do tempo histórico. As personagens citam textos literários umas às outras, permitindo um encontro inusitado de textos com outros textos, alinhavando a história com textos que se deparam com práticas de leitura. Espessura da forma, espessura da história.

Também Leandro Bernardo Guimarães (2016) se volta ao reconhecimento da espessura formal do texto de Bolaño (2008) ao correlacionar memória à memória de leitura em diferentes fragmentos do livro em análise, em que o texto se estrutura como metacrítica e intertextualidade. Um exemplo da defesa da condição heterogênea do texto literário de Bolaño (2008) em Guimarães (2016) se dirige à leitura dos indivíduos compostos no romance como expressões de singularidades que não são necessariamente rompidas pela relação com a memória coletiva: “A memória de leitura projeta uma tendência da literatura contemporânea de não representar exatamente uma voz coletiva, mas, sim, dicções capazes de pensar o indivíduo a partir de múltiplos entrecruzamentos." (GUIMARÃES, 2016: 230).

As características da personagem a aproximam da defesa da condição precária e legítima das testemunhas improváveis. A narradora situada no limiar de referências autobiográficas, jornalísticas, estéticas, teóricas e políticas ajuda outras personagens. A propósito do romance em análise, a atividade da memória, no meio propício da literatura, permite que não se repita 
compulsoriamente o passado, garantindo que Lacouture insira no cerne do seu próprio presente os rastros de passado que ainda concernem a nós.

Há uma pluridimensionalidade do próprio texto literário e da matéria sobre a qual se assenta. Lacouture, como personagem-narradora, delira sobre a história da América Latina, encontrando-se, inesperadamente, com personagens deslocados no tempo cronológico, como é o caso da artista Remédios Varo, pintora surrealista com quem Lacouture se encontra em seu delírio curativo durante parte dos onze dias em que esteve confinada no banheiro feminino da Faculdade de Letras e Filosofia. A personagem-narradora é descrita a partir de características múltiplas, como os cabelos que se encaneciam e os dentes da frente que lhe faltavam. A personagem costumava partilhar a boemia e a sobrevivência à violência de Estado no México, além do gesto de cobrir a boca com a palma da mão, resguardando a discrição e um senso de elegância. Como uma personagem com um “jogo de mãos prodigioso" (BOLAÑO,2008 :31) se torna, justamente, a testemunha da poesia que não se consolidou, dos caminhos sufocados pela violência de Estado e do sangue derramado no chão por onde ainda caminhamos no presente?

A densidade das imagens temporais forjadas pela narrativa de Lacouture nos direciona à composição do texto literário por Bolaño (2008). É ao texto que voltamos, ao tempo da enunciação forjada na literatura, ao entrecruzamento entre as páginas e o desdobramento da vida da personagem, após ter conseguido sair do banheiro feminino. A definitiva pergunta sobre o desaparecimento dos jovens do continente faz com que haja um confronto com o empuxo do presente. Estamos diante de uma experiência de elaboração do passado. Para pensarmos a elaboração do passado, recorremos, também, a Laplanche \& Pontalis (1988), em que se tenta recuperar a dinâmica psíquica que subjaz aos mecanismos inteligíveis do trabalho dos sonhos e dos sintomas individuais nas afecções nervosas investigadas por Sigmund Freud. Mas, além disso, procura-se conectar o trabalho interpretativo na experiência da psicanálise com a própria modificação do estatuto da relação do sujeito que lembra com a experiência traumática que narra, que foi vivenciada no passado².

A explicação de Laplanche e Pontalis (1988) garante uma imersão nos próprios estudos de Sigmund Freud ${ }^{3}$ sobre as distinções entre o trabalho do luto e a melancolia. Fundamentalmente, podemos considerar que, no caso da melancolia, há uma remissão à imaginária identificação do sujeito com o que foi perdido, enquanto que, no luto, se trata da possibilidade de elaboração da perda e de sua eventual metaforização, embora existam muitos 
outros aspectos psicodinâmicos que devam ser considerados numa reflexão específica sobre as vivências ${ }^{4}$. Há um devir para a discussão na obra freudiana, tanto na interpretação clínica quanto metapsicológica. Para os nossos propósitos, é importante considerar que a elaboração política do passado transita pelo trabalho do luto, pela possibilidade de que as dores se tornem enunciáveis e compartilháveis, de modo que a negação do que foi perdido seja interrompida e não se torne empecilho para a continuidade da vida e da consideração do tempo em termos históricos e políticos. O trabalho na experimentação literária e na investigação teórica não pode deixar de considerar que houve uma "perda" e de que essa perda pode ser interpretada à luz das inquietações que nos são colocadas no presente. A psicodinâmica freudiana é parte constitutiva da interpretação que a estudiosa Jeanne Marie Gagnebin formula sobre os contextos de perda subjetiva e política nas ditaduras na América Latina e nos regimes totalitários em outros cenários sociais. No entanto, a noção de sujeito defendida aqui não está apenas remetida a vivências individuais, fornecendo-nos parte das imagens que podemos incluir em nossa interpretação sobre a história.

O impedimento do reconhecimento da perda, a negação do passado e a imposição de uma linearidade com vistas ao futuro sempre distanciado são instrumentos de esvaziamento de nossa relação com o tempo. A concepção de elaboração política aqui discutida se conecta com a proposição da imagem da testemunha como aquela que se constitui tanto na remissão ao que foi vivido e esquecido quanto, fundamentalmente, ao que é lembrado, agora. A testemunha também pode ser, como nos afirma Gagnebin (2006) ao relacionar o legado benjaminiano a outras conceitualizações de testemunha, “(...) aquele que não vai embora, que consegue ouvir a narração insuportável do outro e que aceita que suas palavras levem adiante, como num revezamento, a história do outro(...) não por culpabilidade ou compaixão(...)" (p.57). Na continuidade da discussão, Gagnebin ${ }^{5}$ (2006) ainda considera a centralidade de uma retomada reflexiva do passado de modo a que se possa "inventar" o presente. Para nós, a concepção de testemunha improvável - que testemunha não seria inconcebível, apenas se tornando possível por intermédio do esforço resistente e simbólico que se erige no futuro? - como "aquele que fica" converge com a emergência do próprio campo da psicologia e da psicanálise e, ainda mais fundamentalmente, com a leitura do tempo presente por intermédio da aproximação com as experimentações literárias. A última a ficar na Universidade Nacional Autônoma do México durante a invasão militar em 1968 é a primeira a se tornar testemunha, no livro de Bolaño. 
Os sujeitos escutados por Freud no início do século passado padecem de lembranças e de repetições. A elaboração - ou perlaboração - indica uma temporalidade posterior ao trauma vivenciado, que emerge na experiência onírica e na narrativa do paciente no consultório. Evidentemente que não há coincidência estrita entre elaboração psíquica e literária-política do passado, mas se torna possível defender uma convergência provisória entre as duas, uma vez que se referem à atividade psíquica, narrativa, singular e coletiva sobre o passado que se repete, o passado que nos assombra. Não defendemos uma psicanálise de Lacouture, mas a dignidade da personagem emblemática do romance, uma vez que ela procura despertar, ainda impregnada das imagens do sonho e das profecias que vê serem realizadas na América Latina.

Nas noites na Cidade do México, Auxílio Lacouture chega a envolver-se em um esforço de resgate de uma personagem que estava sendo explorada por um cafetão de rapazes no bairro “colônia" Guerrero, depois que Arturo Belano, personagem essencial na obra de Roberto Bolaño e presente em Amuleto, retorna de uma viagem ao Chile, seu país de origem. Depois de vencer o "Rei dos putos" (o cafetão dos rapazes), Belano, Lacouture, um jovem poeta homossexual e o rapaz explorado entram num táxi que os leva de volta aos lugares supostamente mais seguros em que perambulavam. Lacouture testemunha a engenhosidade com que Belano lida com personagens cruéis, que dominam pelo medo. Parece que Belano as vence pela literatura, encontrando-se no limiar entre o sono e a vigília, reivindicando a grande força política da narrativa diante das imposições de violências cotidianas, ou ainda, do trabalho intermitente da literatura diante da morte. Tal consideração se aproxima, decisivamente, do sentido político da atividade literária, como uma espécie de escrutínio das dores soterradas, da relação com o que perdemos e, mais ainda, com a gana sobrevivente que se dirige ao esboço de temporalidades distintas no tempo histórico homogêneo. A interpretação que se sugere procura posicionar a escrita literária no livro de Bolaño (2008) em destaque como o esboço de temporalidades amplas e inconclusivas.

Num determinado momento do romance de Bolaño (2008) se trata, exatamente, de uma atitude que Lacouture toma em relação à lembrança do golpe de Estado no Chile em 1973 no agora do seu testemunho nervoso sobre a sucessão de histórias de derramamento de sangue na América Latina. Ou seja, a medida em que a narrativa se desenrola, as conexões entre as épocas são testadas e revistas, quando os riscos do passado se dirigem ao presente, forçando relações de continuidade e de ruptura como as que aparecem num sonho, numa lembrança ou num delírio. Conecta-se, tragicamente, o ano de 1968 presente num sonho que Lacouture teve no 
banheiro da Faculdade de Letras e Filosofia da Universidade Nacional Autônoma do México com um sonho em setembro de 1973. Tratar-se-ia de uma premonição? De uma antecipação sobre o que adviria, historicamente?

Nesse setembro de 1973 aparecia o sonho de setembro de 1968, e isso com certeza queria dizer algo, essas coisas não acontecem por acaso, ninguém sai ileso das concatenações, permutações ou disposições do acaso, talvez Arturito já esteja morto, pensei, talvez esse vale solitário seja a figuração do vale da morte, porque a morte é o báculo da América Latina, e a América Latina não pode caminhar sem seu báculo. (BOLAÑO, 2008:57)

Lacouture se lembra dos jovens assassinados em diferentes momentos da história de países da América Latina. Jovens mortos, por exemplo, em Tlatelolco, localidade no México às vésperas das Olimpíadas de 1968 - em que alguns movimentos de resistência ao Estado foram acuados e diluídos por tecnologias de eliminação de "inimigos" internos ao projeto político, econômico e cultural que se vinha estabelecendo oficialmente. Crianças que foram arrancadas da vida, poesias que nunca chegariam a ser lidas, esperanças que nunca deveriam ser desdobradas. O romance de Bolaño (2008) forja linhas transversais em que a reiteração da morte viabiliza que entendamos boa parte de nossa história recente. Recordar e narrar se configuram como antídotos provisórios à simples repetição. A tarefa, aparentemente ingrata, da testemunha do tempo seco aproxima a literatura da problematização do tempo, uma vez que se recolocam questões que não haviam sido levadas em consideração. Recordar e narrar se aproximam daquilo que não havia encontrado espaço de elaboração política, como violências sofridas no decorrer do tempo que não foram reconhecidas nem devidamente problematizadas. Algumas imagens que Lacouture evoca são de existências já findadas, poesias rascunhadas, um céu que escurece na Cidade do México, uma profusão de imagens aparentemente sem sujeito que são contornadas pela narrativa de Lacouture. Imagens que atingem e convidam o leitor contemporâneo a dirigir-se ao seu sanguíneo presente.

A personagem segreda ao leitor os atributos mais fugidios e, paradoxalmente, sobreviventes das coisas do passado. Em seu delirante encontro com Remedios Varo, Auxilio Lacouture é apresentada aos gatos sonâmbulos da Cidade do México e convidada a se aproximar do toca-discos, “(...) um toca-discos velho, o que não tem nada de estranho pois estamos no incrível ano de 1962 e todas as coisas são velhas, todas as coisas levam a mão à boca como eu para sufocar um grito de assombro ou uma confidência inoportuna!" (BOLAÑO, 2008:81). Do encontro improvável - do ponto de vista cronológico - de volta aos ladrilhos do banheiro em que se encontra presa, a personagem desfila um conjunto fértil de representações 
da conexão insuspeita entre o passado e o presente. Retornando de seu delírio, a personagem se sente dirigindo o próprio filme que vê. A personagem é encarada pelas pessoas com quem conversa, às vezes, como se tivesse compreendido, finalmente, que muitas delas já se encontram mortas. São muitos os encontros viabilizados na inusitada condição em que a personagem está. A precariedade do lugar a que está confinada é lembrada outras vezes e o testemunho da personagem se sustenta na constatação dos movimentos que precisam ser feitos para que a narrativa prossiga, incluindo, curiosamente, a finitude da própria narradora.

Pensei: estou no banheiro das mulheres da Faculdade de Filosofia e Letras e sou a última que ficou. Ia em direção à sala de operações. Ia em direção ao parto da História. E também pensei (porque não sou boba): tudo acabou, os granadeiros saíram da universidade, os estudantes morreram em Tlatelolco, a universidade voltou a se abrir, mas eu continuo trancada no banheiro do quarto andar, como se de tanto arranhar os ladrilhos iluminados pela lua eu tivesse aberto uma porta que não é o pórtico da tristeza no continuum do Tempo. (BOLAÑO, 2008:108).

Mas, talvez, a maior força do romance se centre no seu caráter inconcluso, de proposital abertura à leitura. Não se trata de uma fabricação que tenha caráter prescritivo, mas da composição de uma forma que indica a complexidade do exercício reminiscente, do próprio fluxo temporal em que literatura e história convergem e se tensionam. À medida que a testemunha narra, mais questões políticas se somam às suas inquietações inaugurais. Podemos olhar para os rastros do passado como nervura do texto. No texto literário, os mecanismos de disjunção e conjunção entre o tempo da narrativa e a vivência inusitada da personagem no interior do banheiro permitem que muitas imagens se cruzem. Quando se despertará desse sono intranquilo, desses sonhos polissêmicos? Estar presa no banheiro garantiu que a personagem sobrevivesse, mas, paradoxalmente, que ela não presenciasse parte das violências cometidas à geração que foi apagada. Dormir e despertar são verbos importantes na continuidade da narrativa. Despertar se endereça, muitas vezes, ao próprio contexto em que a narradora está/esteve para que o seu testemunho se tornasse possível.

De noite, uma voz, a do anjo da guarda dos sonhos, me perguntava: che, Auxilio, você descobriu onde foram parar os jovens do nosso continente. Cale a boca, eu respondia, cale a boca. Não sei nada. De que jovens está falando. Não sei nada de nada. E então a voz murmurava alguma coisa, dizia mmm, algo assim, como se eu não estivesse muito convencida da minha resposta, e eu dizia: ainda estou no banheiro das mulheres da Faculdade de Filosofia e Letras e a lua derrete um a um todos os ladrilhos da parede até abrir um buraco por onde passam imagens, filmes que falam de nós, das nossas leituras, do futuro rápido como a luz e que não veremos.

Depois sonhava profecias idiotas.

E a vozinha me perguntava, che, Auxilio, o que está vendo? 
O futuro, respondia eu, posso ver o futuro dos livros do século XX. (BOLAÑO, 2008 :112113)

\section{Algumas conclusões provisórias}

Sem abandonar o caráter rasurado e inconcluso da estética que formula, Bolaño (2008) ainda retornará ao trabalho sobre as imagens em relação à literatura que se dirigem ao futuro da América Latina. No suposto percurso da literatura à literatura, Bolaño (2008) resguarda imagens do mundo, de vidas singulares que foram esmagadas, de leituras não terminadas, de estratégias narrativas para que não sejamos, mais uma vez, vencidos. Há dicções marginais no interior do texto literário. E citações de obras literárias que talvez nos ajudem a atravessar os contemporâneos tempos secos.

Profecias, profecias, o que se chama de profecias não sei, mas posso fazer um ou outro prognóstico, replicava eu com a voz pastosa dos sonhos.

Faça, faça, dizia a vozinha francamente entusiasmada.

Estou no banheiro das mulheres da faculdade e posso ver o futuro, dizia eu com voz de soprano e como se me fizesse de rogada.

Eu sei, dizia a voz do sonho, eu sei, comece com as profecias que eu anoto.

As vozes, dizia eu com voz de barítono, não anotam nada, as vozes nem sequer escutam. As vozes só falam. (BOLAÑO, 2008 :113)

Seguem ao momento anterior citações de poetas, literatos, poetisas...Maiakóvski e o ano de 2150, uma reencarnação de James Joyce em 2124, Thomas Mann se convertendo num farmacêutico no Equador de 2101, Proust esquecido a partir de 2033, Marguerite Duras no sistema nervoso de milhares de mulheres em 2035 (Bolaño, 2008:115). São profecias que recolocam a articulação de uma temporalidade política para a arte, especificamente para a literatura, que subsidiam a inquietação com aquilo que se repete para os latinoamericanos e, ao mesmo tempo, com a ressonância dos textos que - deseja-se - perviverão. Na configuração precária da sua narrativa, Lacouture imagina a literatura como antídoto ao tempo linear e, ao mesmo tempo, assenta-se na viabilidade paradoxal das vozes que atravessam o nosso continente e que só se tornam audíveis por que as lemos.

Trata-se de ler as vozes constituídas como textos que dialogam por intermédio da produção de contiguidades intensivas no romance que nos interpela e nos lança ao contemporâneo, como uma oportunidade ética de citar um passado oprimido. No refazimento da condição precária em que se encontra Lacouture, é a própria opacidade do eu como figura retórica que se nutre tanto da forma do texto quanto daquilo que se transmite por intermédio dele. Lembrar é resistir. Dessubjetivando-se como lugar transparente de narração, a personagem 
também se converte na própria recordação, como se percebe na frase "Depois acordei. Pensei: eu sou a recordação." (BOLAÑO, 2008 :124).

O lugar de Lacouture é deslocado pelos comentários feitos a respeito da sua sobrevivência, como a última que esteve na Universidade Nacional Autônoma do México em 1968, a testemunha que chega atrasada a si mesma, aquela que ainda precisará do trabalho literário, a que temos acesso por intermédio da leitura:

Eu continuei vivendo (mas faltava alguma coisa, faltava o que eu tinha visto), e muitas vezes ouvi minha história, contada por outros, na qual aquela mulher que ficou treze dias sem comer, trancada num banheiro, é uma estudante da Faculdade de Medicina ou uma secretária da Torre da Reitoria, e não uma uruguaia sem documentos, sem trabalho, sem casa onde descansar a cabeça. Às vezes nem é uma mulher, mas um homem, um estudante maoísta ou um professor com problemas gastrointestinais. (BOLAÑO,2008:126)

$\mathrm{Na}$ extensão do tempo, ainda haveria um lugar para o que foi sentido e visto pela testemunha. Um lugar ponderado e elaborado na escrita faz a genealogia da personagem e das vozes da geração sacrificada. O procedimento estético em Bolaño pode ser pensado como articulação de uma linha oblíqua na produção de lugares enunciativos. Contra o esquecimento compulsório e as estratégias contemporâneas de apagamento do passado, lembrar é uma espécie de morada da coragem, uma antecipação aos encontros que se podem viabilizar por intermédio do tempo da leitura e da crítica cultural.

A mãe caminhante daqueles jovens estabelece um mapa difuso de dissidências ao totalitarismo. A personagem-narradora se encontra cansada, com diferentes retornos à cena inaugural do romance e se define como aquela que não sucumbiu, uma vez que não esqueceu.

A narrativa se aproxima do fim. Situada no entrecruzamento dos tempos que se desenha por intermédio do jorro narrativo, a personagem se confronta com “(...) uma inacabável legião de jovens que se dirigia a algum lugar.” (BOLAÑO, 2008:129). Jovens que se encaminhavam ao seu sacrifício, cantando. Mas não são todos iguais, não compunham uma massa. Só “generosidade e coragem” (BOLAÑO,2008:129) os unia em uma espécie de comum. A personagem-narradora presta seu tributo aos que foram assassinados, "Sombra ou massa de crianças, caminhavam indefectivelmente para o abismo.” (BOLAÑO, 2008:130). Uma geração que perdeu. A geração assassinada nas ruas, nos porões dos lugares de tortura, nas tensas reiterações do controle estatal-repressivo sobre os movimentos de insurreição nos anos de 1960 e nas décadas posteriores na América Latina. A geração dos poetas que seguiram com seus sonhos breves de tornarem a própria vida, uma obra de arte. 
A personagem-narradora ouve, perplexa, o canto dessa geração, longe demais para não permitir que seguissem para a morte certa. A testemunha sugere que há algo de audível no canto dos jovens que seguem para o seu sacrifício. O canto audível foi parte de sua própria narrativa sempre oblíqua às mesas que foram compartidas e aos desejos que foram interrompidos. A personagem-narradora está impregnada de imagens e de sons que talvez se tornassem insuportáveis se não fossem compartilhados. Chega-se, mais uma vez, à literatura. O texto literário é uma espécie de revide às imagens que concernem aos leitores latino-americanos, que ganhamos um texto sem saber que havíamos perdido uma geração. O que fazer diante do que foi lembrado? A pergunta ética sobre a lembrança encontrou uma forma de desdobramento no próprio procedimento da escrita, uma das possibilidades de elaboração estética e política do passado. Uma ferramenta para a consideração do estatuto político da memória e da subjetividade na produção de uma inteligibilidade sobre nós mesmos e alguns dos nossos maiores desafios.

\section{Referências}

AVELAR, Idelber. Alegorias da derrota: a ficção pós-ditatorial e o trabalho do luto na América Latina. Belo Horizonte: Editora UFMG, 2003.

BENJAMIN, Walter. Magia e técnica, arte e política: ensaios sobre literatura e história da cultura. Tradução de Sergio Paulo Rouanet, 7.ed., São Paulo: Brasiliense, 2008. (Obras Escolhidas, 1)

BENJAMIN, Walter. Passagens. Belo Horizonte: Editora UFMG, 2018.

BOLAÑO, Roberto. Os detetives selvagens. Tradução de Eduardo Brandão. São Paulo: Companhia das letras, 2006.

BOLAÑO, Roberto. Amuleto. Tradução de Eduardo Brandão. São Paulo: Companhia das letras, 2008.

BUTLER, Judith. Vida precária: os poderes do luto e da violência. Belo Horizonte: Autêntica, 2019.

FOUCAULT, Michel. O sujeito e o poder (1982). EM MOTTA, M.B. da. Genealogia da ética, subjetividade e sexualidade: Michel Foucault. Rio de Janeiro: Forense Universitária, 2014

FREUD, Sigmund. Freud (1914-1916) Introdução ao narcisismo, ensaios de metapsicologia e outros textos. Organizado e traduzido por Paulo César de Souza. São Paulo: Companhia das letras, 2010.

GAGNEBIN, Jeanne Marie. História e narração em Walter Benjamin. São Paulo: Perspectiva, 1994.

GAGNEBIN, Jeanne Marie. Lembrar escrever esquecer. São Paulo: Editora 34,2006. 
GIACÓIA Jr, Oswaldo. Messianismo e política em Giorgio Agamben. Reflexão, Campinas, v.7, n.20, p.7-20, 2015. Disponível em https://seer.sis.puccampinas.edu.br/seer/index.php/reflexao/article/view/3229/2140 Acesso 8 abr 2020.

GUIMARÃES, Leandro Bernardo. A memória de leitura na obra Amuleto de Roberto Bolaño. Versalete, Curitiba, v.4, n.7, p.229-245,2016. Disponível em http://www.revistaversalete.ufpr.br/edicoes/vol4-

07/15\%20A\%20mem\%C3\%B3ria\%20de\%20leitura.\%20leandro\%20bernardo\%20guimar\%C3\% A3es.\%20PRONTO.pdf. Acesso 25 out 2019.

KLINGER, Diana. Literatura e ética. Da forma para a força. Rio de Janeiro : Rocco, 2014

LAPLANCHE, Jean; PONTALIS, Jean-Bertrand. Vocabulário de Psicanálise. São Paulo: Martins Fontes, 1988.

PEREIRA, Antonio Marcos; RIBEIRO, Gustavo Silveira (Org.). Toda a orfandade do mundo: escritos sobre Roberto Bolaño. Belo Horizonte: Relicário Edições, 2016.

REVEL, Judith. Dicionário Foucault. Rio de Janeiro: Forense Universitária, 2011.

SELIGMANN-SILVA, Márcio. O local da diferença: ensaios sobre memória, arte, literatura e tradução. São Paulo: Editora 34, 2005.

VERNANT, Jean Pierre. A travessia das fronteiras: Entre mito e política II. Tradução de Mary Amazonas Leite de Barros. São Paulo: Editora da USP, 2009.

Marcelo Santana Ferreira

Instituto de Psicologia, Universidade Federal Fluminense

E-mail: mars.ferreira@yahoo.com.br

\footnotetext{
${ }^{1}$ Optamos por manter a palavra no original em espanhol, por se tratar de um campo de estudos que ganhou grande destaque na língua espanhola sobre parte da literatura latinoamericana, embora as discussões não sejam, necessariamente, concordantes.

${ }^{2}$ No presente artigo, optamos por considerar a perspectiva de Sigmund Freud a partir das leituras forjadas por estudiosos e estudiosas da obra de Walter Benjamin, especificamente Jeanne Marie Gagnebin e Márcio Seligmann-Silva. Não podemos deixar de considerar, no entanto, que uma discussão mais ampla sobre o conceito de elaboração se justifica no tratamento político da nossa relação com o passado. Neste sentido, remetemos os(as) leitores(as) aos livros de Gagnebin(2006) e Seligmann-Silva(2005), em que há capítulos específicos em que se trata, respectivamente, da noção de elaboração psíquica e política do passado e da noção de real como aquilo que não se define por intermédio de uma representação final. Para os propósitos do presente artigo - estabelecer uma convergência e, ao mesmo tempo resguardar as singularidades dos textos e obras citados -, entendemos que as discussões cumprem uma função pontual significativa.

${ }^{3}$ A referência que utilizamos foi a de Freud (2010)

4 Judith Butler (2019) faz uma discussão política importante sobre a experiência do luto na contemporaneidade, ao pensar o intervencionismo estadunidense em outros países, tomando o devido cuidado ao indicar que sua concepção de sujeito não implica numa coincidência entre Estado e experiência de si, tendo a psicanálise oferecido parte das importantes imagens sugeridas para se estabelecer uma analítica da precariedade e da sujeição.

${ }^{5}$ No capítulo especificamente citado, a estudiosa está debruçada sobre o testemunho de Primo Levi a respeito das atrocidades cometidas aos prisioneiros do campo de concentração de Auschwitz. Apropriamo-nos da imagem da testemunha, remetendo-a à função de acompanhar e ouvir uma narrativa, por mais dolorosa que seja.
} 